\title{
Research into unplanned purchases on the Serbian market
}

\author{
Suzana Đukić \\ Faculty of Economics, University of Niš, Niš, Serbia \\ Jelena Stanković \\ Faculty of Economics, University of Niš, Niš, Serbia
}

\begin{abstract}
Purchases of products and services are mainly the result of planned actions of consumers based on identified needs and desires. However, impulse purchases that consumers did not plan before entering the store are quite common as well. Such purchases are stimulated by the consumers' sudden needs, current mood, recommendations of the seller and/or other consumers, as well as in-store incentives such as: the atmosphere in the sales facility, discounted prices, gifts. Also, numerous innovations make impulse buying easier for consumers, like: flexible working hours of shops, affordable supply of products/services, online sales, offer of so-called "instant" loans, the existence of ATMs. Unplanned purchases are not exclusively a consequence of the impulse-driven reaction of consumers. In addition to pure impulsiveness, there are other types of unplanned purchases, such as: suggestion effect, planned impulsivity, reminder impulse buying effect, and planned purchase of a certain type, but not brand of product. The aim of this paper is to point out the importance and basic characteristics of unplanned purchases, as well as the factors that influence consumer behavior while making such purchases. Conducted empirical research enabled the identification of the most important motives of unplanned purchases made by consumers in the Republic of Serbia, their frequency in buying different product categories, the connection of different shopping situations with unplanned purchases, as well as the determination of differences between certain demographic and economic groups of consumers in making such purchases. The research results and their analysis enabled the formulation of guidelines for the development of marketing strategies of companies from the Republic of Serbia as a model of response to this type of consumer behavior.
\end{abstract}

\section{Keywords}

consumers, unplanned purchases, motives, shopping situations, the Republic of Serbia

\section{Introduction}

The study of consumer behavior represents the primary focus of marketing research. Information about consumer behavior in different shopping situations increases the rationality of marketing decisions and improves their effects. The dynamics of consumers' needs and desires, their selectivity, the combination of different motives, the impact of different purchasing factors and situations require that research of consumer behavior be a constant activity in the company. Generation of valuable information and knowledge about consumers significantly reduces the market risk that exists in marketing decision making.
Purchases of goods and services can be planned or unplanned. Authors agree that purchases are predominantly planned consumer actions since they are driven by defined needs and motives (Peter \& Olson, 2010; Solomon, 2009; Hawkins \& Mothersbaugh, 2010; Maričić, 2011). However, many purchasing decisions are not planned by consumers before entering the sales facility. According to some research, unplanned purchases make up $62 \%$ of all purchases, and this percentage is thought to be even higher in online purchases (Chamorro-Premuzic, 2015). Therefore, unplanned purchases represent a growing source of income for retailers (Bell, Corsten \& Knox, 2011; Inman, Winer \& Ferraro, 2009). 
Impulse and unplanned purchases should not be equated. Impulsive behavior when purchasing reflects the tendency of consumers to buy spontaneously, non-reflectively, immediately, while unplanned behavior basically refers to the buying decision that was made without a deliberate plan before buying (Kacen, Hess \& Walker, 2012). Unplanned purchases are characterized by a sudden desire to buy, lack of cognition in assessing product attributes, mental imbalance caused by comparing current satisfaction and long-term consequences of such purchases, lack of consideration of possible consequences of such behavior (Maričić, 2011).

Given the importance of unplanned purchases in formulating marketing strategies of the company, the authors of this paper focused their research on identifying such behavior in shopping by consumers in the Republic of Serbia. The research is concentrated on the analysis of the frequency of motives, i.e. incentives that encourage consumers to make such purchases, as well as on their share in certain product groups. Taking into consideration the growth of companies' investment in activities that encourage such purchases, the research also included the impact of demographic and economic characteristics of respondents on the propensity for unplanned purchases that are driven by various external factors (physical and social environment, time of purchase, specific situation). The aim is to obtain information on the characteristics and frequency of unplanned purchases in the Republic of Serbia, which is crucial for formulating recommendations to the marketing management.

The paper is structured as follows. The first part of the paper is dedicated to a review of the relevant literature on the characteristics and types of unplanned consumer purchases on the basis of which research hypotheses are defined. The second part explains the research methodology. The third part presents the results of the research and their discussion. In the conclusion of the paper, recommendations are given to managers in the Republic of Serbia and research limitations are explained.

\section{Review of literature and research hypotheses}

Impulsiveness as a characteristic of consumer behavior in shopping is often considered a qualifying determinant of unplanned purchases.
However, pure impulsiveness is only one type of unplanned purchases and implies a situation in which a specific purchase surpasses the usual consumer behavior and which is stimulated by the current emotional need. Such purchases are related to the purchase of products that are new to the consumer and/or products that meet consumer's desire for diversity in retail. These are "sudden and immediate" purchases with no preshopping intention to do so. "Impulse buying is initiated by a spontaneous feeling for the purchase without much thinking about its consequences" (Beatty \& Ferrell, 1998). "Impulse buying is the result of a conflict between the consumer's desire and self-control" (Verplanken \& Sato, 2011) or a conflict between the desire and willingness, where affective state exceeds reflection (Coley \& Burgess, 2003; Herabadi, Verplanken \& Van Knippenberg, 2009; Hoch \& Loewenstein, 1991). Recent studies have shown that pure impulse buying makes up an increasingly significant percentage of the total purchase of consumers in modern conditions (Amos, Holmes \& Keneson, 2014).

Impulsiveness in purchases results from the effects of internal factors (personality, selfregulation disorder and habits) and external stimuli (marketing stimuli of the company) (Dholakia, 2000; MacInnis \& Patrick, 2006). Internal factors that affect impulse buying vary from individual to individual. Thus, for example, Sneath, Lacey and Kennett-Hensel (2009) have argued that impulse buying purchase can be realized due to the individual's depression and effort to improve mood. Verplanken and Herabadi (2001) obtained similar results and linked impulse shopping with individuals who want to escape from negative psychological perceptions such as low self-esteem, negative feelings or poor spirits. Marketing stimuli stand out as the most important external factors. Marketers design external stimuli to attract the attention of consumers. Managers spend a lot of time and effort designing a retail environment, and are focused on the interaction between sales staff and customers to increase the psychological motivation of customers to purchase (Berry, Seiders \& Grewal, 2002). Therefore, unplanned purchasing can be triggered by various marketing incentives such as product position on the shelf, communication with sales staff, atmosphere in sales facilities, discounted prices, product demonstrations and the like (Mohan, Sivakumaran \& Sharma, 2013). 
In addition to pure impulsiveness, there are the following types of unplanned purchases: suggestion effect, planned impulsivity, reminder effect, and planned purchase of a certain category but not brand of a product (Stern, 1962, cited by Assael, 1998). The suggestion effect is a situation where a consumer has no prior knowledge about a particular product, but acquires it in the store based on its characteristics. If a consumer goes shopping without preconceived resoluteness to buy a specific brand of product, it is so-called planned impulsiveness. There are many situations when a consumer, in addition to planned purchases, also buys products that are not planned, and that are singled out by promotional activities in the store (products with special discounted prices, seller's recommendation, sound or lighting effects, etc.). This is the so-called reminder impulse buying effect. Also, there are situations when the consumer plans to buy a category of products, but not a brand. The specific brand in these situations becomes the consumer's choice only in the store.

According to the results of numerous studies, unplanned purchases have had a dominant share in the total sales of companies in recent decades (Ek Styvén, Foster \& Wallström, 2017; Kacen et al., 2012). Such a situation is the result of intensive investments in marketing activities to which consumers are exposed and thus motivated to this type of purchase. Leading investments are in sales promotion activities including point-ofsale activities, but also different elements of the physical environment and personal selling activities. The growth of unplanned purchases is also connected with numerous innovations that have enabled simpler and faster consumer purchases, such as: online purchases, TV sales, telemarketing. Such purchases require significantly less time, effort, energy and expenditures, but are, on the other hand, subject to large impacts on consumers by companies. Mass media significantly support these company activities.

Unplanned consumer behavior is conditioned by the specific situation in which a purchase is carried out. Such situations are determined by various factors. The following are dominant: physical environment, social environment, time of purchase (season, morning, evening), sudden state of mind and specific situation (Assael, 1998).

It has been empirically proven that the physical environment influences a consumer's specific decision about the purchase. The physical environment consists of the location of the sales facility, the degree of urbanization of the sales environment, crowd level, arrangement of the sales facility, air conditioning, etc. The social environment includes the influence of reference groups, but also the kindness and influence of sales staff on the choice of products and services.

The time of purchase is another factor that determines shopping behavior. Many products and services are designed to save time and efforts of consumers in shopping. Specific purchases may require different levels of consumer engagement depending on whether products are bought for personal use or as a gift.

Sudden state of mind (impulse) can be caused by consumers' mood, other socio-psychological factors, as well as sales promotion activities. Mood can be influenced by the physical environment (music, fragrance, decoration etc.), weather conditions or social environment (family, friends). According to Shapiro (1992), the main factors that initiate impulse purchases are: location, time of purchase, season and habits of consumers. In the case larger purchases are made, the possibility of making impulse purchases grows as well. Also, the more time spent in the store, the greater the opportunity to buy on impulse. The relationship between the store environment and the consumer's impulsive mood is moderated by a situational factor, such as time $(\mathrm{Xu}, 2007)$. The consumer's available time determines the stay in the store and the feelings, which may result in impulse purchasing decisions.

According to Lee and Ariely (2006), the impact of promotional activities on stimulating unplanned consumer purchases varies depending on the stage of the purchasing process and its objectives. If consumers have more explicit shopping goals, they are less susceptible to the influence of promotional activities. The impact of a company's promotional actions is, however, greater at the beginning of the purchase process, when consumer shopping goals are not yet fully defined. Research has shown that the savings that a consumer can make in purchases affect the gradual increase in unplanned purchases exceeding the so-called planned basket of goods (Stilley, Inman \& Wakefield, 2010). The intensity of that increase gets higher with the increase in the consumer economic power.

In particular, sales promotion tools are of great importance for providing information to consumers at the point of sale, reminding, stimulating good mood and suggesting unplanned 
purchases. According to research (Osman, Fah \& Foon, 2011; Tinne, 2011; Banerjee \& Saha, 2012; Rittipant, Kheawwilai, Suayngam, Promsoot \& Vivatanaprasert, 2013; Nagadeepa, Selvi \& Pushpa, 2015), price discounts represent the instrument of sales promotion that motivates consumers to unplanned buying behavior more than any other instruments. The results of research in the Republic of Serbia which agree with these studies showed that price discounts, bonus packs and premiums are the most efficient means for motivating impulse consumer behavior (Alimpić \& Perić, 2019). Also, Heilman, Nakamoto and Rao (2002) confirm that consumers who receive unexpected coupons in the store realize more unplanned purchases, which are derived from "psychological income" or the effect of a better mood. These sales promotion tools are clear and consumers understand them easily. Accordingly, consumers can relatively easily assess the benefits they get by purchasing. One study has shown that special price discounts have a positive impact on unplanned expenditure (Aydinli, Bertine \& Lambrecht, 2014) because they reduce reflection, shorten the time of purchase and increase the emotional response of consumers. In view of these research results, we started from the following hypothesis:

\section{H1: Discounts are the most important motive} for unplanned purchases.

Unplanned consumer behavior can be related to the purchase of different product groups. The question is: in which product group is such consumer behavior more pronounced? In answering this question, we started from the fact that unplanned purchases largely imply a lack of thinking, the influence of emotions and a sudden desire for certain products. In this, both the value of the product and the characteristics of the consumer are taken into account. According to some research, the consumption of soft drinks and fast food is higher among younger generations of consumers. On the other hand, the demand for sports and recreational services is higher in consumers aged 45 and over, while the demand for medical and telephone services, travel, food is higher in consumers over 65 (Evans \& Berman, 1997; Jobber \& Fahy, 2006; Littrel, Paige \& Song, 2004). Stern (1962, cited by Assael, 1998) points out that different product benefits affect impulse buying. Functional benefits, for example, often motivate consumers to make impulse purchases (Schiffman \& Kanuk, 2007). The results of one study showed that confectionery products are the best-selling impulse products especially during travel (Crawford \& Melewer, 2003). The situation is similar with the purchase of books, but also with exercise equipment (Yu \& Bastin, 2010). This confirms the view that the concept of impulse buying is also applicable to durable consumer goods (Kumar, 2007). For example, colors and different designs of clothing and footwear evoke positive emotions in consumers and often influence the impulsive reaction in purchases (Park, Kim \& Forney, 2006).

Proceeding from the above, empirical research is focused on testing frequency of unplanned purchases in the purchase of the following product groups: food products, books/magazines, footwear/clothing, cosmetics/personal hygiene and household devices/appliances. Respondents were given the opportunity to include another group of products that they buy unplanned, which is not in the offered list of answers. Starting from the key characteristics of unplanned purchases and perceived risk in the purchase of certain products, we are of the opinion that this type of shopping is more frequent in the purchase of food products. Accordingly, the following hypothesis was formulated:

H2: Food products are the most common group of products that are bought unplanned.

Consumers behave differently in different shopping circumstances and situations. Thus, for example, behavior differs when consumers buy alone or accompanied, when they have enough time and when they do not have it, when they buy products for personal needs or as a gift. Information obtained from sellers as well as from friends during a purchase can increase the chances for an impulse purchase (Yu \& Bastin, 2010). Luo (2005) points out that impulsiveness in shopping increases if purchase is made in the presence of friends, but that this need decreases in the presence of family members. In this matter, one should keep in mind the connection between consumer loyalty and consumer inclination towards such purchases. There are studies that have shown that the kindness of sales staff directly affects impulse shopping (Mattila \& Wirtz, 2008).

Gender is one of the important demographic characteristics that influences consumer behavior 
in the shopping process. In this connection, the differences in the behavior of men and women should be considered, as well as the differences in their preferences and the ways of collecting and processing information (Mitchell \& Walsh, 2004). Some studies indicate that women are more impulsive compared to men in shopping (Priyanka \& Rooble, 2012; Jalees, 2009; Virvilaite, Saladiene \& Bagdonaite, 2009). On the other hand, there are also attitudes that men are more impulsive in their purchases than women, because women carefully plan their purchases (Mai, Jung, Lantz, Loeb, 2003).

In addition to gender, the age structure of consumers also influences shopping behavior. Different age groups of consumers react differently to the interior design of sales facilities, sudden situations in which they can find themselves, recommendations and information they receive from sellers, etc. Research shows that, for example, impulsive behavior is more dominant in people between the ages of 18 and 39 (Wood, 2005). In this, it is also important to consider the employment status of consumers.

Based on these facts, the intention in the research was to identify differences in consumer behavior in different shopping situations with regard to the demographic characteristics of the respondents (gender, age, employment status). In this sense, the following hypothesis is defined:

H3: Demographic characteristics of the respondents determine their behavior in different shopping situations.

The study of economic factors is essential to explain the behavior of people in the process of purchasing. The size of income, inclination to spend or save, opportunity to obtain consumer loans, alongside with personal characteristics and lifestyle, including the broader context of economic environment, that is, general economic conditions and economic climate, largely determine the needs and requirements of consumers, priorities in meeting them, as well as criteria in the product/brand evaluation process. In particular, inclination to spend and save depends on the level of consumers' purchasing power. Although some studies argue that there is no link between income and unplanned purchases (Ghani et al., 2011; Yang et al., 2011), it is rational to examine whether the inclination toward planned/unplanned purchasing behavior is related to purchasing power of respondents, especially when it comes to higher value products. However, customer retention is a major profit driver in today's saturated market environment. In view of this, the following hypothesis is defined:

H4: There is an impact of respondents' monthly income on the frequency of unplanned purchases.

\section{Research methodology}

Research method and instrument. Testing of research hypotheses is based on empirical research that was conducted using the method of testing. A questionnaire structured as follows was used to gather information. First questions that were asked referred to the assessment of the frequency of motives, that is, incentives for unplanned purchases, and then questions related to the frequency of such behavior in the purchase of different product categories. At the end of the questionnaire, statements are formulated to test the occurrence and frequency of unplanned shopping behavior in relation to external factors that determine different purchasing situations (physical environment, social environment, time, sudden state of mind and specific situation when buying products/services) (Overview 1). All questions in the questionnaire are of the closed type, and the degree of the respondents' agreement with the stated statements was expressed by using the 5-Point Likert Scale, where point 1 means "completely disagree" and point 5 "completely agree".

\begin{tabular}{c|l}
\multicolumn{2}{c}{ Overview 1 Overview of statements } \\
\hline \multirow{4}{*}{$\begin{array}{c}\text { Physical } \\
\text { environment }\end{array}$} & $\begin{array}{l}\text { I like to shop when there is cheerful music in } \\
\text { the store }\end{array}$ \\
\cline { 2 - 2 } & I like to shop when the store is crowded \\
\cline { 2 - 2 } & $\begin{array}{l}\text { The fragrance in the store affects my } \\
\text { purchase }\end{array}$ \\
\hline \multirow{2}{*}{$\begin{array}{c}\text { Social } \\
\text { environment }\end{array}$} & $\begin{array}{l}\text { I rather shop in a company than when I am } \\
\text { alone }\end{array}$ \\
\cline { 2 - 2 } & I often shop when I am with my family \\
\hline \multirow{4}{*}{ Time } & I go shopping when I have free time \\
\cline { 2 - 2 } & I prefer to go shopping in the afternoon \\
\cline { 2 - 2 } & I love shopping on weekends \\
\hline \multirow{3}{*}{$\begin{array}{c}\text { Sudden state } \\
\text { of mind }\end{array}$} & When I am in a good mood, I go shopping \\
\cline { 2 - 2 } & Discounts in the store affect my purchase \\
\cline { 2 - 2 } & $\begin{array}{l}\text { If I like something at first sight, I buy it } \\
\text { without thinking }\end{array}$ \\
\hline \multirow{2}{*}{$\begin{array}{c}\text { Specific } \\
\text { situation }\end{array}$} & I like to shop while travelling \\
\cline { 2 - 2 } & I enjoy buying gifts \\
\hline
\end{tabular}

Source: The authors 
Research context. The survey was conducted on the territory of Serbia. The number of distributed online questionnaires was 200 , and all were completed and processed.

Sample characteristics. In the sample structure, males participated with $41.5 \%$, while there were more females and they made up $58.5 \%$ of respondents. In terms of age, the structure of respondents was as follows: $14 \%$ were respondents under the age of $20,42.5 \%$ were respondents aged 21 to $35,26.5 \%$ were respondents aged between 36 and 50 and $17 \%$ who were 51 and older. In terms of status, $34 \%$ of respondents were students, the largest number or $38.5 \%$ of respondents in the sample were employed, there were $15.5 \%$ unemployed respondents, while pensioners made $12 \%$ of the sample. The structure of respondents on the basis of monthly income was as follows: $26.5 \%$ of respondents earned up to 15,000 dinars, the largest percentage, that is $40.5 \%$ of respondents belong to the group with monthly income from 15001 to 35000 dinars, $24 \%$ of respondents had monthly income from 35001 to 55000 dinars and only $9 \%$ of respondents were with 55001 and more dinars of income.

Analyses and procedures. Statistical processing and analysis of data was performed using software packages Microsoft Excel and SPSS (Statistical Package for Social Science, 21.0). From statistical analyses, appropriate descriptive measures were used, multivariate analysis of variance (MANOVA) was used, as well as analysis of variance (ANOVA). The assumptions that need to be tested in order to use ANOVA and MANOVA have been confirmed.

\section{Research results}

In order to test the first hypothesis, descriptive statistics were applied to analyze the frequency of occurrence of motives, i.e. incentives for unplanned purchases. Using a five-point scale of importance, respondents rated the importance of the following incentives: product quality, discounts (special discounted prices, quantity discounts, cash discounts), other sales promotion techniques (bonus packs, coupons, premiums) and brand image. The results of the analysis revealed that discounts are the most important motive for unplanned purchases, with an average score of 4.16. Other sales promotion techniques were ranked second by respondents with an average score of 3.85 , followed by product quality with an average score of 3.82 and brand image with the lowest average score of 3.47.

Based on the previous results in Table 1, it can be concluded that the first hypothesis that discounts are the most important motive for unplanned purchases has been confirmed.

Table 1 Descriptive measures of unplanned purchase motives

\begin{tabular}{l|c|c|c}
\hline Motives & $\mathrm{N}$ & Mean & Std. Deviation \\
\hline Product quality & 200 & 3.82 & .882 \\
\hline Discounts & 200 & 4.16 & .831 \\
\hline $\begin{array}{l}\text { Other sales promotion } \\
\text { techniques (bonus packs, } \\
\text { coupons, premiums) }\end{array}$ & 200 & 3.85 & 1.263 \\
\hline Brand image & 200 & 3.47 & 1.138 \\
\hline Valid N (listwise) & 200 & & \multicolumn{3}{|c}{ Source: Calculation by authors }
\end{tabular}

The same statistical analysis was applied to test the second hypothesis, and the results are shown in Table 2.

The obtained results represent the percentage share of particular product groups. Food products have the highest percentage of $48.5 \%$. Cosmetics and personal care products are in the second place with the share of $26 \%$. Other data on groups of products that are purchased unplanned are shown in the table.

Taking the results below into account, it can be concluded that the second hypothesis has been confirmed. The results are justified considering that food products are bought every day, unlike other product groups, so that the probability of their unplanned purchase is higher.

Table 2 Percentage share of product groups

\begin{tabular}{l|c|c|c|c}
\hline Product groups & $\begin{array}{c}\text { Freque } \\
\text { ncy }\end{array}$ & Percent & $\begin{array}{c}\text { Valid } \\
\text { Percent }\end{array}$ & $\begin{array}{c}\text { Cumulative } \\
\text { Percent }\end{array}$ \\
\hline $\begin{array}{l}\text { Books/ } \\
\text { magazines }\end{array}$ & 7 & 3.5 & 3.5 & 3.5 \\
\hline $\begin{array}{l}\text { Footwear/ } \\
\text { Clothing }\end{array}$ & 27 & 13.5 & 13.5 & 17.0 \\
\hline $\begin{array}{l}\text { Cosmetics/ } \\
\text { personal hygiene }\end{array}$ & 52 & 26.0 & 26.0 & 43.0 \\
\hline $\begin{array}{l}\text { Appliances/ } \\
\text { household devices }\end{array}$ & 17 & 8.5 & 8.5 & 51.5 \\
\hline Food products & 97 & 48.5 & 48.5 & 100.0 \\
\hline \multicolumn{1}{c|}{ Total } & 200 & 100.0 & 100.0 & \multicolumn{3}{|c}{ Source: The authors } \\
\hline & & &
\end{tabular}

Multivariate analysis of variance (MANOVA) was used to test the third hypothesis. Before testing the hypothesis, we checked the 
consistency of the statements, that is, the value of the Cronbach's alpha coefficient was calculated and the obtained values for all dimensions are higher than the recommended value of 0.7 (Nunnally, 1978). The obtained results are shown in Table 3 and they present the internal consistency.

Table 3 The value of the Cronbach's alpha reliability coefficient for the scale

\begin{tabular}{l|c}
\hline Variables & Cronbach's alpha \\
\hline Physical environment & .764 \\
\hline Social environment & .873 \\
\hline Time & .718 \\
\hline Sudden state of mind & .842 \\
\hline Specific situation & .772 \\
\hline
\end{tabular}

The value of alpha coefficient, which is closer to 1 than to 0 for all variables, means that the applied variables have an excellent level of reliability, i.e. they are suitable for measuring the attitudes and opinions of end consumers.

Table 4 The influence of demographic and economic characteristics on the behavior of respondents in different situations of unplanned purchases

\begin{tabular}{c|c|c|c|c|c|c}
\hline \multicolumn{7}{|c|}{ MANOVA - Wilks' Lambda } \\
\hline Effect & Value & $F$ & $\begin{array}{c}\text { Hypothesis } \\
\text { df }\end{array}$ & Error df & Sig. & $\begin{array}{c}\text { Partial } \\
\text { Eta } \\
\text { Squared }\end{array}$ \\
\hline Gender & .958 & $1.057 \mathrm{a}$ & 8.000 & 191.000 & .395 & .042 \\
\hline Age & .622 & 4.074 & 24.000 & 548.759 & .000 & .147 \\
\hline $\begin{array}{c}\text { Employment } \\
\text { status }\end{array}$ & .464 & 5.020 & 32.000 & 694.905 & .000 & .174 \\
\hline $\begin{array}{c}\text { Monthly } \\
\text { income }\end{array}$ & .628 & 3.985 & 24.000 & 548.759 & .000 & .144 \\
\hline
\end{tabular}

Source: Calculation by authors

The results of multivariate analysis of variance in our study indicate statistical significance in age, social status and monthly income, while in the variable Gender the results are not statistically significant.

The value of Wilks' Lambda in the variable Gender (Sig. $=0.395)$ is not statistically significant, i.e. there is no significant influence of gender on different situations of unplanned purchase. On the other hand, the values of the Wilks' Lambda the variable Age $($ Sig. $=0.000)$, the variable Status $(\mathrm{Sig} .=0.000)$ as well as the variable Monthly income $(\mathrm{Sig} .=0.000)$ are statistically significant. The results obtained in this way indicate that there is a statistically significant influence between the researched demographic and economic characteristics and the behavior of respondents in different shopping situations (Table 5).

Table 5 MANOVA results - the influence of the age of respondents on the behavior in different situations of unplanned shopping

\begin{tabular}{c|l|c|c|c}
\hline Source & Dependent Variable & $\mathbf{F}$ & Sig. & $\begin{array}{c}\text { Partial Eta } \\
\text { Sq. }\end{array}$ \\
\hline \multirow{5}{*}{ Age } & $\begin{array}{l}\text { I like to shop when the } \\
\text { store is crowded }\end{array}$ & 8.079 & .000 & .110 \\
\cline { 2 - 5 } & $\begin{array}{l}\text { When I am in a good } \\
\text { mood, I go shopping }\end{array}$ & 4.255 & .006 & .061 \\
\hline $\begin{array}{l}\text { If I like something at } \\
\text { first sight, I buy it } \\
\text { without thinking }\end{array}$ & 12.379 & .000 & .159 \\
\cline { 2 - 5 } $\begin{array}{l}\text { Discounts in the store } \\
\text { affect my purchase }\end{array}$ & 8.868 & .000 & .120 \\
\hline \multicolumn{4}{|c|}{ Source: Calculation by authors }
\end{tabular}

In view of the results shown in Table 5, we can conclude that there are significant age-related differences between respondents in terms of behavior in different unplanned shopping situations. The physical environment, i.e. the statement: "I like to shop when the store is crowded" mostly affects the respondents in the age group of 21 to 35 with an average score of 3.81. The remaining statements belong to sudden states of mind that lead to impulsiveness in consumer behavior. The results of our research indicate that the strongest impulsive reaction is shown by respondents aged 21 to 35 when it comes to the statements "Discounts in the store affect my purchase" with an average score of 4.33 and "If I like something at first sight, I buy without thinking" with an average score of 3.89, while the statement "When I'm in a good mood, I go shopping" mostly affects the group of respondents who are over 51 years old with an average score of 4.62 .

Table 6 MANOVA results - the influence of the employment status of the respondents on the behavior in different situations of unplanned purchases

\begin{tabular}{c|l|c|c|c}
\hline Source & Dependent Variable & $\mathbf{F}$ & Sig. & $\begin{array}{c}\text { Partial } \\
\text { Eta Sq. }\end{array}$ \\
\hline \multirow{5}{*}{$\begin{array}{l}\text { Employment } \\
\text { Status } \\
\text { affect my purchase }\end{array}$} & $\begin{array}{l}\text { Ilike to shop when there is } \\
\text { cheerful music in the store }\end{array}$ & 10.044 & .000 & .171 \\
\hline & $\begin{array}{l}\text { I go shopping when I have } \\
\text { free time }\end{array}$ & 8.590 & .000 & .150 \\
\cline { 2 - 5 } & $\begin{array}{l}\text { When I am in a good } \\
\text { mood, I go shopping }\end{array}$ & 4.208 & .003 & .079 \\
\hline $\begin{array}{l}\text { If I like something at first } \\
\text { sight, I buy it without } \\
\text { thinking }\end{array}$ & 13.920 & .000 & .222 \\
\hline
\end{tabular}




\begin{tabular}{l|l|l|c|c|c}
\hline $\begin{array}{l}\text { like to shop while } \\
\text { travelling }\end{array}$ & 5.049 & .001 & .094 \\
\hline $\begin{array}{l}\text { Ilike to shop when the } \\
\text { store is crowded }\end{array}$ & 5.748 & .000 & .105 \\
\hline \multicolumn{4}{c}{ Source: Calculation by authors }
\end{tabular}

Having in mind the results from Table 6, we can conclude that there is a statistically significant influence between the respondents of different employment status and their behavior in different unplanned purchasing situations. The variable: employment status is most affected by the following situations: characteristics of the physical environment, time and sudden state of mind. In particular, the physical environment: "I like to shop when there is cheerful music in the store" has the greatest impact on pensioners with an average score of 4.50 , while time with the statement: "I go shopping when I have free time" most affects the group of employees with an average score of 4.17 , which is a rational answer. This is consistent with the studies which proved that the frequency of unplanned purchases is higher if consumers spend more time shopping (Park et al., 2006). The specific situation, i.e. the statement "I like to shop while traveling", mostly affects the group of employees with an average score of 4.1. The remaining statements apply to sudden purchasing situations. According to the results of our research, employees react unplanned in purchases when it comes to discounts with an average score of 4.47 , when they are in a good mood with an average score of 4.62 and when they buy at first sight with an average score of 3.94. The remaining groups of respondents have a lower average score according to all statements concerning unplanned reactions in case of sudden purchasing situations.

The impact of monthly income on different situations of unplanned purchases differs according to all statements, as well as with the variable: employment status. The only difference is that with this variable the statement "I like to shop when the store is crowded" has no statistically significant impact. It should be noted that the statement "I like to shop while traveling" has the greatest impact on respondents with a monthly income of 55,000 dinars and more, with an average score of 4.44. The results are justified given that respondents with higher purchasing power travel more, which increases the possibility of unplanned reactions to shopping on trips.

By analyzing the results, we can conclude that the third hypothesis is partially confirmed, since we have not proved that the variable Gender affects behavior in different situations of unplanned purchases, while the results for the remaining variables are confirmed.

To test the fourth hypothesis, analysis of variance (ANOVA) was used. The value of Levene's test for homogeneity of variance was greater than 0.05 , which means that we did not violate the assumption of variance homogeneity so we can proceed with further analysis of variance.

Table 7 ANOVA results - the impact of monthly income of the respondents to the frequency of unplanned purchases

\begin{tabular}{c|c|c|c|c|c}
\hline & $\begin{array}{c}\text { Sum of } \\
\text { Squares }\end{array}$ & $\mathrm{df}$ & $\begin{array}{c}\text { Mean } \\
\text { Square }\end{array}$ & $\mathrm{F}$ & Sig. \\
\hline $\begin{array}{c}\text { Between } \\
\text { Groups }\end{array}$ & 41.350 & 3 & 13.783 & 16.370 & .000 \\
\hline $\begin{array}{c}\text { Within } \\
\text { Groups }\end{array}$ & 165.030 & 196 & .842 & & \\
\hline Total & 206.380 & 199 & & & \\
\hline \multicolumn{6}{c}{ Source: Calculation by authors }
\end{tabular}

Based on the results from Table 7 , we conclude that there is a statistically significant impact of monthly income on frequency of unplanned purchases, because the obtained $p$ value is less than 0.05 . Further, based on the results from the ANOVA table, we can calculate the eta squared, i.e. the strength of the effect, which ranges from 0 to 1 . Eta squared is calculated as the ratio between the sum of squares of the deviations of different groups $(41,350)$ and the total sum of squares $(206,380)$. In our case, the obtained strength of the effect is 0.2 , which indicates that the effect is significant. In order to clearly determine between which groups based of monthly income there is a statistically significant difference, the Post Hoc test, that is, Tukey's HSD test was analyzed. It was found that there is a statistically significant difference between the first group of respondents (up to 15,000 RSD), and other groups related to the frequency of unplanned purchases. The results are justified considering that respondents with a monthly income amounting up to $15,000 \mathrm{RSD}$ are less likely to make unplanned purchases compared to other groups of respondents with higher levels of income.

Based on the analysis of the results, we can conclude that the fourth hypothesis has been confirmed, or in other words, that monthly income has an impact on the frequency of unplanned purchases. 


\section{Discussion}

Empirical research in this paper is aimed at identifying key determinants of unplanned purchases in the Republic of Serbia. According to the research results, discounts are the most important motive for making unplanned purchases, which confirmed the first hypothesis. Discounts are a consequence of the company's operation through various promotional activities, and sales promotion activities are one of the initiators of unplanned consumer reactions, especially of pure impulse reactions. Such results were confirmed by numerous studies (Osman et al., 2011; Tinne, 2011; Banerjee \& Saha, 2012; Rittipant et al., 2013; Nagadeepa, Selvi \& Pushpa 2015).

Empirical research has shown that food products are the most common group of products that are purchased unplanned. The obtained results are expected, due to both the value of these products and the characteristics of the process of their purchase. By virtue of the results obtained in this way, we confirmed the second hypothesis as well. In accordance with the above, food safety represents a current topic, with significant implications and diverse approaches within the specialized literature. In the context of globalization and integration of agricultural markets, the necessity of guaranteeing food safety is imperative for the functionality of contemporary agricultural systems

The third hypothesis was partially confirmed, considering that it has not been proven that the studied demographic characteristics of the respondents determine their behavior in different shopping situations. Differences in the gender of respondents did not show such variances. It should be pointed out that in all other researched variables of the respondents (age, employment status) a positive connection was established with the statements related to sudden situations, which means that there is an impact on unplanned consumer behavior.

Testing of the fourth hypothesis showed that monthly income influences the frequency of unplanned purchases, i.e. that the frequency of unplanned purchases increases proportionally with the growth of monthly income. It is worth noting that companies should not expect that increase in the purchasing power of consumers will be enough to achieve the desired effects. In order to succeed in this, companies must conform their marketing strategies to different phases of the product life cycle.

\section{Conclusion}

Successful marketing strategies are based on understanding the needs, desires and behaviors of consumers. Purchases of products and services are mainly determined by planned consumer actions. However, apart from the planned purchases, there are also so-called unplanned purchases. These are the purchases that consumers do not plan before going shopping, i.e. in advance, but make them directly in the store, under the influence of certain factors. Starting from the fact that consumer behavior can be planned and unplanned, this paper is focused on the characteristics, types and frequency of unplanned purchases, as well as on their relationship with the characteristics of consumers.

Proceeding from the results of the research, the strategy of stimulating unplanned purchases should be based on the use of discounts, as well as on their combination with other means of sales promotion, especially those at the point of sale. The aim is to take advantage of the point of sale due to the potential consumer's contact with the product on the one hand and the potential consumer's personal contact with the sales staff on the other. In this respect, merchandising and organizing product demonstrations together with a number of other means in the store (shelves, printed materials, so-called wobblers, posters, demonstration cards, illuminated banners and displays) may give the desired effects. These means are aimed at drawing the attention of consumers, creating favorable conditions for attracting consumers and inducing them to purchase. The combination of product exposition, decorative elements and physical appearance, i.e. color, light, sound and video effects, should create an attractive ambience, confidence in product quality and a positive overall atmosphere in the store.

Online sales are, in the modern business environment, a significant form of stimulating unplanned purchases. Creating personalized and interactive business website and advertising sales on social networks are just some of the possibilities to stimulate purchases. E-manuals must focus on creating a hedonistic experience of consumers (Park, Kim, Funches \& Foxx, 2011). Strategies that have already been intensively applied by companies to stimulate online 
shopping are based on attractive prices (lower than in offline sales), cross-selling, giving away gifts with the purchased product in order to tie the consumer to the brand and to increase sales.

According to the results of research which showed that food products are most often bought unplanned, the strategy of developing their online purchase should focus on spreading sensory experiences and positive recommendations and on developing a positive atmosphere during their consumption. An interactive presentation based on the use of tools that provide this option, such as chatbots or virtual assistants, can produce the desired effects.

In our study, we did not prove that gender as a demographic variable affects unplanned purchases. However, as we have already pointed out that there are different results regarding the unplanned reaction in purchases in relation to gender, our proposal is that companies should, accordingly, adapt to the differences in the behavior of men and women by applying content personalization. This strategy also proves rational when it comes to different age groups of consumers and their economic strength.

Coverage and size of the sample are the most important limitations of empirical research. Moreover, the paper discussed product groups, but not individual products and brands. In other words, it will depend on the price category to which a certain product/brand belongs, i.e. on its value, whether it will be purchased unplanned. Despite all the above limitations of this preliminary research, it is important because certain conclusions that can be drawn in conformity with it may represent a starting point in considering new market challenges.sm

\section{References}

Amos, C., Holmes, G.R., \& Keneson, W.C. (2014). A metaanalysis of consumer impulse buying. Journal of Retailing and Consumer Services, 21 (2), 86-97. https://doi.org/10.1016/j.jretconser.2013.11.004

Assael, H. (1998). Consumer Behaviour and Marketing Action, Cincinnati, Ohio: Western Publishing College.

Aydinli, A., Bertine, M., \& Lambrecht, A. (2014). Price promotion for emotional impact. Journal of Marketing, 78(4), 80-96. https://doi.org/10.1509/jm.12.0338

Alimpić, S. Perić, N. (2019). Različiti oblici impulsivnog ponašanja potrošača. Anali Ekonomskog fakulteta $u$ Subotici, 55(42), 049-063 https://doi.org/10.5937/AnEkSub1942049A

Banerjee, S., \& Saha, S. (2012). Impulse buying behaviour in retail stores - triggering the senses. Asia Pacific Journal of Marketing \& Management Review, 1(2), 1-21.
Beatty, S. E., \& Ferrell, M. E. (1998). Impulse buying: Modeling its precursors. Journal of Retailing, 74(2), 169-191.

https://doi.org/10.1016/S0022-4359(99)80092-X

Bell, D., Corsten, D., \& Knox, J. (2011). From point of purchase to path to purchase: How preshopping factors drive unplanned buying. Journal of Marketing, 75(1), 3145.

https://doi.org/10.1509/jm.75.1.31

Berry, L. L., Seiders, K., \& Grewal, D. (2002). Understanding service convenience. Journal of Marketing, 66(3), 1-17. https://doi.org/10.1509/jmkg.66.3.1.18505

Chamorro-Premuzic, T. (2015). The Psychology of Impulsive Shopping. The Guardian, November 26

Coley, A., \& Burgess, B. (2003). Gender differences in cognitive and affective impulse buying. Journal of Fashion Marketing and Management: An International Journal, 7(3), 282-295.

https://doi.org/10.1108/13612020310484834

Crawford, G., \& Melewar, T. C. (2003). The importance of impulse purchasing behavior in the international airport environment. Journal of Consumer Behavior, 3(1), 8598.

https://doi.org/10.1002/cb.124

Dholakia, U. M. (2000). Temptation and resistance: an integrated model of consumption impulse formation and enactment. Psychology \& Marketing, 17(11), 955-982. https://doi.org/10.1002/15206793(200011)17:11<955::AID-MAR3>3.0.CO;2-J

Ek Styvén, M., Foster, T., \& Wallström, A. (2017). Impulse buying tendencies among online shoppers in Sweden. Journal of Research in Interactive Marketing, 11(4), 416- 431. https://doi.org/10.1108/JRIM-05-2016-0054

Evans, J. R., \& Berman, B. (1997). Marketing, 7th edition, New York: Macmillan Publishing Company.

Ghani, U., Imran, M., \& Jan, F. A. (2011). The impact of demographic characteristics on impulse Buying behavior of urban consumers in Peshawar. International Journal of Academic Research, 3(5), 286289.

Hawkins, I. D., \& Mothersbaugh, L. D. (2010). Consumer Behavior Building Marketing Strategy, New Jersey: Prentice-Hall, Inc.

Heilman, C. M., Nakamoto, K., \& Rao, A. G. (2002). Pleasant Surprises: Consumer Response to Unexpected In-Store Coupons. Journal of Marketing Research, 39(2), 242-252. https://doi.org/10.1509/jmkr.39.2.242.19081

Herabadi, A. G., Verplanken, B., \& Van Knippenberg, A. (2009). Consumption experience of impulse buying in Indonesia: Emotional arousal and hedonistic considerations. Asian Journal of Social Psychology, 12(1), 20-31. https://doi.org/10.1111/j.1467-839X.2008.01266.x

Hoch, S. J., \& Loewenstein, G. F. (1991). Time-inconsistent preferences and consumer self-control. Journal of Consumer Research, 17(4), 492-507. https://doi.org/10.1086/208573

Inman, J. J., Winer, R. S., \& Ferraro, R. (2009). The interplay among category characteristics, customer characteristics, and customer activities on in-store decision making. Journal of Marketing, 73(5), 19-29. https://doi.org/10.1509/jmkg.73.5.19 
Jalees, T. (2009). An Empirical Analysis of Impulsive Buying Behavior in Pakistan. International Review of Business Research Papers, 5(6), 298-308.

Jobber, D., \& Fahy, J. (2006). Osnovi marketinga (drugo izdanje), Beograd: Data Status.

Kacen, J. J., Hess, J. D., \& Walker, D. (2012). Spontaneous selection: The influence of product and retailing factors on consumer impulse purchases. Journal of Retailing and Consumer Services, 19(6), 578-588. https://doi.org/10.1016/j.jretconser.2012.07.003

Kumar, R. (2007). Marketing and Branding: Indian Scenario. Pearson Education, 325-326.

Lee, L., \& Ariely, D. (2006). Shopping Goals, Goal Concreteness, and Conditional Promotions. Journal of Consumer Research, 33(1), 60-70. https://doi.org/10.1086/504136

Littrel, M., Paige, R., \& Song, K. (2004). Senior Travelers: Tourism Activities and Shopping Behaviours. Journal of Vacation Marketing, 10(4), 348-62. https://doi.org/10.1177/135676670401000406

Luo, X. (2005). How does shopping with others influence impulsive purchasing. Journal of Consumer Psychology, 15(4), 288-294. https://doi.org/10.1207/s15327663jcp1504 3

Maclnnis, D. J., \& Patrick, V. M. (2006). Spotlight on affect: Affect and affective forecasting in impulse control. Journal of Consumer Psychology, 16(3), 224-231. https://doi.org/10.1207/s15327663jcp1603 4

Mai, N.T.T., Jung, K., Lantz, G., \& Loeb, S. G. (2003). An Exploratory Investigation into Impulse Buying Behavior in a Transitional Economy: A Study of Urban Consumers in Vietnam. Journal of International Marketing, 11(2), 13-35. https://doi.org/10.1509/jimk.11.2.13.20162

Maričić, B. (2010). Ponašanje potrošača (deveto izdanje), Beograd: Ekonomski fakultet.

Mattila, A. S., \& Wirtz, J. (2008). The role of store environmental stimulation and social factors on impulse purchasing. Journal of Services Marketing, 22(7), 562567. https://doi.org/10.1108/08876040810909686

Mitchell V. W., \& Walsh, G. (2004). Gender Differences in German Consumer Decision-making Styles. Journal of Consumer Behaviour, 3(4), 331- 46. https://doi.org/10.1002/cb.146

Mohan, G., Sivakumaran, B., \& Sharma, P. (2013). Impact of store environment on impulse buying behavior. European Journal of Marketing, 47(10), 1711-1732. https://doi.org/10.1108/EJM-03-2011-0110

Nagadeepa, C., Selvi, T. J., \& Pushpa, A. (2015). Impact of Sales Promotion Techniques on Consumers' Impulse Buying Behaviour towards Apparels at Bangalore. Asian Journal of Management Sciences \& Education, 4(1), pp. 116-124.

Nunnally, J.C. (1978) Psychometric theory. 2nd Edition, New York: McGraw-Hill

Osman, S., Fah, B. C. Y., \& Foon, Y. S. (2011). Simulation of Sales Promotions towards Buying Behavior among University Students. International Journal of Marketing Studies, 3(3), 78-88. https://doi.org/10.5539/ijms.v3n3p78
Park, E. J., Kim, E. Y., \& Forney, J. C. (2006). A structural model of fashion-oriented impulse buying behavior. Journal of Fashion Marketing and Management, 10(4), 433-446. https://doi.org/10.1108/13612020610701965

Park, E. J., Kim, E. Y., Funches, V. M., \& Foxx, W. (2011). Apparel product attributes, web browsing, and eimpulse buying on shopping websites. Journal of Business Research, 65(11), 1583-1589. https://doi.org/10.1016/j.jbusres.2011.02.043

Peter, J. C., \& Olson, C. J. (2010). Consumer Behavior and Marketing Strategy. New York: McGraw-Hill/Irwin.

Priyanka, V., \& Rooble, V. (2012). An on-field-survey of the impulse buying behavior of consumers in consumer non-durable sectors in the retail outlets in the city of Indore, India. Research Journal of Management Sciences, 1(4), 1-5.

Rittipant, N., Kheawwilai, D., Suayngam, N., Promsoot, S., \& Vivatanaprasert, T. (2013). Thai Consumers Response to Sales Promotions for Personal Care Products. Proceedings of the 4th International Conference on Engineering, Project and Production Management, 700709.

https://doi.org/10.32738/CEPPM.201310.0063

Schiffman, L.G., \& Kanuk, L.L. (2007). Consumer Behavior 9th edn., New Jersey: Prentice Hall.

Shapiro, J. M. (1992). Impulse buying: A new framework. Developments in Marketing Science, 15, 76-80. https://doi.org/10.1007/978-3-319-13248-8 16

Sneath, J. Z., Lacey, R., \& Kennett-Hensel, P. A. (2009). Coping with a natural disaster: Losses, emotions, and impulsive and compulsive buying. Marketing Letters, 20(1), 45-60. https://doi.org/10.1007/s11002-008-9049-y

Solomon, R. M. (2009). Consumer Behaviour: Buying, Having, and Being (8th ed.). New Jersey: Pearson Education.

Stilley, K. M., Inman, J. J., \& Wakefield, K. L. (2010). Spending on the Fly: Mental Budgets, Promo-tions, and Spending Behavior. Journal of Marketing, 74(3), 34-47. https://doi.org/10.1509/jmkg.74.3.34

Tinne, S. W. (2011). Factors Affecting Impulse Buying Behavior of Consumers at Superstores in Bangladesh. ASA University Review, 5(1), 209-20.

Verplanken, B., \& Herabadi, A. (2001). Individual differences in impulse buying tendency: feeling and no thinking. European Journal of Personality, 15(S1), S71S83. https://doi.org/10.1002/per.423

Verplanken, B., \& Sato, A. (2011). The psychology of impulse buying: An integrative self-regulation approach. Journal of Consumer Policy, 34(2), 197-210. https://doi.org/10.1007/s10603-011-9158-5

Virvilaite, R., Saladiene, V., \& Bagdonaite, R. (2009). Peculiarities of impulsive purchasing in the market of consumer goods. Commerce of Engineering Decisions, 2, 101-108.

Wood, M. (2005). Discretionary Unplanned Buying in Consumer Society. Journal of Consumer Behavior, 4(4), 268-81. https://doi.org/10.1002/cb.14 
Xu, Y. (2007). Impact of Store Environment on Adult Generation Y Consumers' Impulse Buying. Journal of Shopping Center Research, 14(1), 39-56.
Yu, C., \& Bastin, M. (2010). Hedonic shopping value and impulse buying behavior in transitional economies: Asymbiosis in the Mainland China marketplace. Journal of Brand Management, 18(2), 105-114. https://doi.org/10.1057/bm.2010.32

\section{$\bowtie$ Correspondence}

\section{Suzana Đukić}

Faculty of Economy, University of Niš

Trg kralja Aleksandra Ujedinitelja 11, 18105, Niš, Serbia

E-mail: suzana.djukic@m.ekonomski.rs 